\title{
Kriminalitetskontroll eller sikkerhetspolitikk?
}

Mareile Kaufmann, mareile.kaufmann@jus.uio.no

Postdoktor, Institutt for kriminologi og rettssosiologi, Universitetet i Oslo

Kriminalitetskontroll og sikkerhetspolitikk glir stadig mer over $i$ hverandre, både når det gjelder retorikk og arbeidsmetoder. For å forstå hvorfor fenomener som tidligere kunne blitt behandlet som nasjonale politisaker og kriminalitet i dag blir definert som sikkerhetsproblemer, kan det vare nyttig a ta i bruk perspektiver utviklet innenfor kritiske sikkerhetsstudier. I denne artikkelen vil jeg se narmere på tre slike perspektiver: det narrative, som omhandler sikkerhet og språk; det praktiske, som omhandler sikkerhet og handlinger; og det materielle, som omhandler sikkerhet og ting.

Fra 1990-tallet, og særlig etter at 'krigen mot terror' kom på den politiske dagsordenen etter angrepene i USA 11. september 2001, har sikkerhetspolitikk og kriminalitetskontroll i stadig større grad blitt vevd sammen. Både i Europa og USA glir saker og strategier som tidligere har blitt ansett å tilhøre forskjellige politiske ansvarsområder, over i hverandre. For eksempel blir fra politisk hold voldelig kriminalitet som massenedskytinger definert som krisesituasjoner, unntakstilstander eller til og med som krig (Bush 2002) - begreper og tilstander som opprinnelig tilhørte den internasjonale sikkerhetspolitikkens språk og domene. Aradau og van Munster beskriver dette fenomenet som «katastrofenes politikk» (2011), og Garland har vist i sine analyser hvordan kriminalitetskontroll er blitt påvirket av «sikkerhetstankegang» (1996). Også i Norge ser vi en utvikling i denne retningen, for eksempel med opprettelsen i 2012 av Justis- og beredskapsdepartementet med ansvarsområde som omfatter både kriminalitetsbekjempelse og krisehåndtering (Regjeringen 2015a).

Jeg skal skissere hvordan de to feltene blir stadig mer sammenvevd. Aktører fra eksterne tjenester, som forsvaret, og interne tjenester, som politiet, er i stadig større grad involvert $\mathrm{i}$ hverandres arbeid. Både språkbruk og de faktiske oppgavene innen sikkerhetspolitikk og kriminalitetskontroll overlapper mer og mer. Denne sammenkoblingen gir i neste omgang mer dyptgående endringer: de to feltene utvikler felles måter å tenke om og å forklare problemer på, og metodene de benytter, blir stadig mer lik hverandre.

Jeg mener kritiske sikkerhetsstudier kan bidra til å forstå denne sammenkoblingen bedre. Med kritiske sikkerhetsstudier henviser jeg til den konstruktivistiske dreiningen innen 
sikkerhetsforskningen som startet på 1990-tallet. Etter at den kalde krigens bi-polare sikkerhetssituasjon forsvant og nye sikkerhetsutfordringer og -aktører vokste frem, ble rådende sikkerhetsteorier i stor grad ansett som utilstrekkelige og etter hvert erstattet av nye perspektiver (jf. Burgess 2010). Det var her nye måter å se på sikkerhet vokste frem. Disse var kritiske til tidligere perspektiver som så på sikkerhet og usikkerhet som gitte størrelser. Innenfor kritiske sikkerhetsstudier ble lingvistiske, performative og kulturelle perspektiver viktige for å problematisere sikkerhetspolitikk, -teknologi, -praksis og -logikk. Ulike forestillinger om sikkerhet og usikkerhet er sentrale for slike studier, hvilket betyr at man ikke tar fenomenene for gitt. Målet er å kontekstualisere og å vise hvordan ulike redskaper og praksiser blir til. Hvorfor og hvordan blir noe et spørsmål om sikkerhet eller usikkerhet? Det betyr også at kritiske sikkerhetsstudier ikke er nøytrale, men politiske - de endrer det som studeres, og setter spørsmålstegn ved makt, rettferdighet og autoritet (jf. Salter og Mutlu 2013).

Jeg skal se nærmere på tre viktige perspektiver innenfor kritiske sikkerhetsstudier som knytter an til og viderefører metodologiske tradisjoner fra henholdsvis Michel Foucault, Pierre Bourdieu og Bruno Latour: det narrative, som omhandler sikkerhet og språk; det praktiske, som omhandler sikkerhet og handlinger, og det materielle, som omhandler sikkerhet og ting. Det er ikke klare grenser mellom disse tre perspektivene, men inndelingen kan likevel hjelpe til med å rydde i de forskjellige temaene, teoriene og metodene som har dukket opp de siste tiårene innenfor kritiske sikkerhetsstudier. Jeg skal se nærmere på hvordan disse tre perspektivene kan anvendes i studiet av terrorbekjempelse, og jeg skal trekke frem eksempler som viser hvordan ulike tilnærminger til sikkerhet skaper uklare grenser mellom forvaltningen av henholdsvis kriminalitetskontroll og sikkerhetspolitikk i Norge.

\section{Sikkerhet og språk - det narrative perspektivet}

Når sikkerhetsmyndigheter og media bruker begrep som «terrorisme» og «radikalisering», «fremmedkrigere» og «islamisering» for å beskrive hendelser og fenomener, påvirker dette samfunnsdebatten og hvordan man ser på disse hendelsene og fenomenene. Valget av begrep kan på sikt føre til spesielle sikkerhetstiltak, for eksempel endringer i asylpolitikken, militære tiltak eller overvåking av enkelte minoriteter. Derfor er det viktig å undersøke nærmere hvilke begreper myndigheter og media bruker når det snakkes om kriminalpolitikk og samfunnssikkerhet, hvilke diskurser vi kan identifisere, og hvordan disse har endret seg over tid. Det narrative perspektivet 
ser altså på hvordan sikkerhet blir kommunisert - ikke bare hvordan visse begreper brukes i bestemte situasjoner, men også hvordan en viss språkbruk gjenspeiler politiske posisjoner og påvirker politisk praksis.

Den vanligste metoden for å utforske denne innflytelsen, er diskursanalyse. Diskurs betyr i denne sammenheng «en gruppe utsagn som gir et språk for å snakke om [...] et bestemt emne i et bestemt historisk øyeblikk» (Hall 1997: 44, min overs.). Diskurs kan inkludere alle typer kommunikasjon, også for eksempel visuell kommunikasjon. I henhold til Hall (ibid.) viser diskurs alltid til produksjon av mening, som i sin tur former det vi giør. Diskursanalyser undersøker hvordan kunnskap, meninger og standpunkter pakket i diskurser er direkte relatert til makt og politisk praksis. Bruk av spesielle uttrykk i juridiske og politiske tekster og uttalelser, som for eksempel «beredskap», har direkte konsekvenser for måten sikkerhetstiltak vedtas på, og hvem slike tiltak er rettet mot.

Det analytiske målet for narrative perspektiver er dermed å dekonstruere diskurser om sikkerhetsspørsmål for å forstå hvilke retoriske verktøy som brukes, hvem som snakker til hvem, og hvordan alt dette påvirker beslutninger, handlinger og reaksjoner. Ett eksempel er det vi kan kalle sikkerhetiseringsteori (Securitization Theory) (Wæver 1995), som tar dette perspektivet videre ved å analysere hvordan ulike aktører faktisk gjør et fenomen til et sikkerhetsspørsmål, for eksempel ved å knytte bestemte begivenheter til begrepet «radikalisering». Sikkerhetiseringsteori skiller seg altså fra teorier om sikkerhet som har som utgangspunkt at det finnes faktiske sikkerhetstrusler 'ute i verden', og at forskerens oppgave er å identifisere dem for politikerne som skal håndtere problemene (f.eks. Waltz 1959). Sikkerhetiseringsteorien tar heller utgangspunkt i at det ikke nødvendigvis er slik at noe der ute er mer farlig enn noe annet, men at myndighetene velger å definere og forholde seg til noe som sikkerhetsproblem(er). For når noen definerer noe ikke bare som et problem, men et sikkerhetsproblem, innebærer dette også at de sier at løsningen finnes i sikkerhetspolitikkens repertoar. Det betyr at visse, noen ganger ekstraordinære, tiltak kan rettferdiggjøres for å håndtere dette sikkerhetsproblemet. Ved å definere noe som et sikkerhetproblem, konstrueres altså både sikkerhetsproblemet og reaksjonen på sikkerhetsproblemet (Wæver 1995).

Sikkerhetisering innebærer altså at et fenomen blir konstruert som et spørsmål om sikkerhet, og Wæver definerer ulike betingelser som må tilfredsstilles for at en slik prosess skal være 
vellykket: aktørene som snakker om sikkerhet og usikkerhet må allerede ha eller skaffe seg autoritet på det aktuelle saksområdet, for eksempel som representanter for myndigheter eller media; de som potensielt blir påvirket av en trussel må utgjøre et meningsfylt fellesskap, for eksempel det norske folk, nasjonen eller staten; trusselen må være eksistensiell og bekjempelsen må rettferdiggjøre ekstraordinære tiltak, som for eksempel vold og hemmelighold; og det relevante publikum må akseptere fremstillingen av både trusselen og tiltakene slik dette blir presentert av de relevante aktørene (ibid.). Sikkerhetiseringsteori handler altså om å forstå hvem som lykkes i å definere at noe er et sikkerhetsproblem, men også hvordan og hvorfor: Hvordan er terrorisme og ekstremisme blitt etablert som trusler som krever ekstraordinære sikkerhetstiltak? Hvilke løsninger ville man fått hvis terrorisme i stedet ble definert som et 'ordinært' kriminalitetsproblem?

Hva kan det narrative perspektivet tilføre studiet av sikkerhet og terrorbekjempelse? Myndighetene presenterer ofte terrorisme som et problem knyttet til usikkerhet og uforutsigbarhet. Dette er fremtredende både når terrorisme i Norge betraktes som et lovbrudd (straffeloven 2005 § 131-146) og når den betraktes som en form for krigføring, hvilket er vanligere i USA. President George W. Bush var den første som brukte uttrykket «krigen mot terror», da som et språklig startpunkt og argument for USAs invasjon av Irak som en del av «ondskapens akse» (Bush 2002). Selv om ikke alle definisjoner av terrorisme inneholder begrepet usikkerhet, er usikkerhet likevel alltid viktig i den politiske diskursen. Bush' forsvarsminister Donald Rumsfeld kalte terrorisme for «de ukjente ukjentes utfordring» (Rumsfeld 2002), altså trusler som man ikke kan vite noe om, og som myndighetene ikke engang er klar over at de ikke vet noe om. «Radikal usikkerhet» er et annet uttrykk som har vært fremme i debatten om terrorisme (Aradau og van Munster 2011). I likhet med «de ukjente ukjentes utfordring» fremstiller dette terrorisme som en eksistensiell trussel, og det er svært vanskelig å vite på forhånd hvor, når og hvordan trusselen opptrer. Det har ført til at politikere og eksperter krever ekstraordinære tiltak som overvåking, kroppsskanning og nye profileringsteknikker.

Terrorbekjempelse har altså blitt et spørsmål om forebygging, om å hindre faren før den inntreffer. Nettopp her nærmer terrorbekjempelsen seg den forebyggende kriminalitetskontrollens metoder. 
Når internasjonal terrorisme blir presentert som en eksistensiell og samtidig uforutsigbar forbrytelse i global skala, knyttes bekjempelsen av terrorisme til et språk om forebygging og lokal beredskap. Beredskap er et gammelt fenomen, ikke minst i form av militære og sivile øvelser, men når beredskap blir knyttet til terrorbekjempelse og «usikkerhetens politikk» (Aradau og van Munster 2011), blir den integrert i et nytt domene som involverer borgeren selv og lokale institusjoner (Kaufmann 2017). Beredskapslogikken blir stadig utvidet og er i økende grad til stede i våre daglige liv. Når måten man snakker om usikkerhet og beredskap på kobles sammen, har dette konkrete virkninger: på grunn av terrorismens globale omfang og dens eksistensielle uforutsigbarhet, lover ikke lenger myndighetene å avverge den kriminelle terrorismen - hensikten med beredskap blir i stedet å kontrollere krisen etter at et anslag er skjedd. Gjennom språket redefineres hele forestillingen om sikkerhet: siden terrorisme er vanskelig å kontrollere på forhånd, er sikkerhet ikke lenger et løfte om beskyttelse mot fare, og individene er ikke lenger bare potensielle ofre. Med beredskap menes i denne konteksten at hele samfunnet forventes å godta farens eksistens og å være forberedt på å hjelpe til i en krisesituasjon, for så å gjenopprette sikkerheten i fellesskap. Nye ord som «resiliens» og «motstandsdyktighets-diskursen» gjenspeiler denne trenden.

At Justis- og politidepartementet skiftet navn til Justis- og beredskapsdepartementet etter 22. juli 2011, er et godt eksempel på hvordan kriminalitetskontroll og sikkerhetspolitikk nærmer seg hverandre. Samtidig knyttes diskurser om usikkerhet og beredskap tettere sammen. Denne endringen kan, med Wæver (1995), beskrives som en vellykket sikkerhetisering: Ikke bare er den usikre fremtiden blitt et sikkerhetsproblem, men navnet på Justis- og beredskapsdepartementet er også relatert til et konkret sett med retningslinjer og praksiser for å takle dette problemet.

\section{Sikkerhet og handling - det praktiske perspektivet}

En annen måte å studere terrorbekjempelse på, er å se på handlinger som er utført innenfor rammen av programmer for bekjempelse av terrorisme. Dette praktiske perspektivet ser på «organiserte former for handling» (Bueger 2017: 126, min overs.). Det innebærer at man ikke bare studerer tekst, men ofte er fysisk ganske nær fenomener man studerer, fordi forskningsmetodene er basert på empiri og feltarbeid. For eksempel kan man gjennom feltarbeid oppdage at programmer for kontraterrorisme ikke nødvendigvis inneholder et sett av innbyrdes logiske handlinger, men kan motsi hverandre. Et prinsipp også for det praktiske perspektivet er 
derfor at sikkerhet ikke er noe på forhånd gitt som eksisterer 'der ute', men springer ut av mange forskjellige handlinger. Disse praksisene kan være forskjellige former for «kroppslige aktiviteter, [...] mentale aktiviteter, 'ting' og deres bruk, [...] fagkunnskap, tilstander knyttet til emosjonell og motivasjonsrelatert kunnskap» (Reckwitz 2002: 249, min overs.).

Metoder som ser på hvordan sikkerhet praktiseres, er ofte inspirert av arbeidet til Pierre Bourdieu. Med utgangspunkt i Bourdieu kan sikkerhet betraktes som et spesielt praksisfelt. Feltet organiseres av regler som ikke nødvendigvis er skrevet ned eller formalisert (Bourdieu kaller disse reglene doxa), og aktører bringer praktisk kunnskap til dette feltet (habitus), der de forskjellige aktørene konkurrerer om status og ressurser (capital) (Bourdieu 1972). Formålet for det praktiske perspektivet er å identifisere og beskrive alle disse elementene, noe som kan være vanskelig fordi de kan endre seg over tid og fra sted til sted. For eksempel har Didier Bigos forskning på sikkerhetsaktører som arbeider med migrasjon på tvers av Europa, vist at sikkerhet ikke nødvendigvis bare ivaretas av de store sikkerhetsaktørene, men i like stor grad er resultatet av helt normale hverdagslige praksiser og rutiner, som for eksempel administrative vurderinger og utfylling av skjemaer (Bigo 2002). Slik får vi øye på andre aktører i sikkerhetsfeltet, som byråkrater og sikkerhetsfagfolk. Bigos forskning viser også at det skjer en generell forskyvning i sikkerhetspraksiser mot større samarbeid mellom interne og eksterne sikkerhetsaktører (f.eks. mellom politi og militære) som danner felles komiteer og organisasjoner (ibid.), og som sammen utgjør et internasjonalt sikkerhetsfelt. Dette er også svært synlig innenfor grensesikkerhet, som er blitt viktig for terrorbekjempelse (Côté-Boucher et al. 2014). Slike detaljerte analyser av handlinger, beslutninger og administrative prosedyrer viser at sikkerhet ikke er et gitt fenomen, men snarere noe som blir til i praksis i et felt med ulike aktører, kunnskaper og maktforhold.

Hva kan det praktiske perspektivet tilføre studiet av sikkerhet og terrorbekjempelse? Siden 1970tallet, og særlig siden den globale krigen mot terror startet i 2001, har for eksempel mange av oppgavene til politiet, etterretningstjenesten og militæret blitt omorganisert. Grensene er blitt utvisket «mellom den kriminelle og fienden, mellom sivil beskyttelse i tilfelle en krisesituasjon og sivilforsvar i tilfelle en trussel, mellom beskyttelse av den offentlige orden [...] og krigstilstand» (Balzacq et al. 2010: 5, min overs.). Denne omorganiseringen innebærer ikke bare et bytte av oppgaver og roller, som for eksempel at politifolk sendes på utenlandsoppdrag eller at militær kunnskap blir brukt for å styrke den interne sikkerheten. Det innebærer også at det 
oppstår helt nye oppgaver hvor grensene for indre og ytre tiltak endrer seg og kan anta flere former på samme tid.

I Norge har politiets arbeid tradisjonelt vært delt mellom interne og eksterne oppgaver. Justis- og beredskapsdepartementet skiller mellom Politidirektoratet (POD), som har ansvar for interne oppgaver, og Politiets sikkerhetstjeneste (PST), som har ansvar for rikets sikkerhet og eksterne oppgaver. Men i dag har forskjellige praksiser og profesjoner i sikkerhetsfeltet også begynt å fusjonere. Ett eksempel på dette er det økte samarbeidet mellom POD og PST for å skape bevissthet om og redusere radikalisering og for å forebygge ekstremisme (Regjeringen 2016). Dette samarbeidet omfatter opplæring av tjenestemenn så de kan takle de viktigste problemene og utvikle tiltak mot dem. Her kan særlig de ordinære politistyrkene bidra med lokalkunnskap og nærhet til folk på et område som tidligere lå under sikkerhetstjenesten. Et annet eksempel på at det foregår en fusjonering av interne og eksterne oppgaver, er at POD har fått en egen «beredskapsdirektør» - det er altså opprettet en ny stilling for krisehåndtering i det ordinære politiet (Trædal 2016). Et tredje eksempel er, som nevnt tidligere, at det tidligere Justis- og politidepartementet nå heter Justis- og beredskapsdepartementet, og at oppgavene som har med kriminalitetsbekjempelse og krisehåndtering å gjøre, nå ligger hos samme departement (Regjeringen 2015a). Politiavdelingens seksjon for planlegging og forskning dekker både områder innen kriminalpolitikken og innen kriseberedskapen (Regjeringen 2015b).

Disse tre eksemplene illustrerer hvordan skillet mellom interne og eksterne oppgaver viskes ut, og at det i sikkerhetsfeltet oppstår nye praksiser og samarbeidsformer på tvers av fagområder og profesjoner.

Sikkerhet og ting - det materielle perspektivet

Mens praksisperspektivet utforsker forskjellige måter å håndtere sikkerhet på, prøver forskere ved hjelp av det materielle perspektivet å forstå rollen ting, utstyr og materiell spiller i sikkerhetspolitikken. Eksempler på dette kan være bruk av våpen i politiarbeid, overvåkingskameraer i bekjempelsen av vandalisme, eller spesielle dataprogrammer for profilering av gjerningsmenn. Ting, spesielt teknologier, blir her betraktet som redskaper i prosessen med å sikre samfunnet mot trusler. Og disse redskapene blir ikke bare behandlet passivt av forskjellige brukere. Noen forskere vil heller si at redskapene har egenskaper og 
kvaliteter som skaper muligheter for noen former for bruk, men ikke for andre. Et overvåkingskamera kan for eksempel gjøre synlige ting kjent for brukere, men ikke usynlige. Ifølge Bruno Latour er både mennesker og ting aktører, fordi de eksisterer i et nettverk av relasjoner som etablerer betydningen av både tingen, det tingen brukes til, og mennesket. Dette nettverket av relasjoner må alltid reaktiveres for at det ikke skal forsvinne (Latour 2005).

Andre forskere på feltet vil hevde at bare sammen kan mennesker og ting skape virkelighet (Aradau 2010; Barad 2007). Ting er altså ikke særlig forskjellige fra mennesker i den forstand at de også spiller en aktiv rolle i sikkerhetspraksiser og - som mennesker - kan endre seg over tid. Ting er «hverken faste eller gitt» (Aradau 2010: 498, min overs.), og når mennesker og ting handler gjennom hverandre, vil de også forandre hverandre. Begge får nye betydninger og funksjoner, egenskaper og grenser. Derfor er det materielle perspektivet opptatt av hvilken rolle ting og materiell spiller i sikkerhetspolitikk - hvordan ting opprettholdes, hvordan de endrer seg, og hvordan de forsvinner fra den politiske scenen. Eksempler på ting som er interessante når man studerer sikkerhet, kan være kritisk infrastruktur (Aradau 2010) eller kroppsskannere på flyplasser (Bellanova og Gonzales-Fuster 2013). En annen ting som er spesielt viktig for å føre sammen feltene og teknikkene fra sikkerhets- og kriminalitetskontrollen på nye måter, er digital informasjon. Det skal jeg se nærmere på nå.

Hva kan det materielle perspektivet tilføre studiet i sikkerhet og terrorbekjempelse, for eksempel hvis vi ser på betydningen av digital informasjon? Digital teknologi utvikler seg raskt og blir stadig mer tilgjengelig, også for dem som driver med sikkerhet og kriminalitetskontroll. Dette gjelder alt fra informasjon delt på sosiale medier til GPS-signaler fra telefonen. Fordi digitale data kan telles, beregnes, lagres, søkes og spores (Kaufmann og Jeandesboz 2016), spiller digital informasjon - sammen med konteksten den brukes $\mathrm{i}$ - en viktig rolle $\mathrm{i}$ endringen av sikkerhetspraksiser. Det gir mulighet til flere samarbeidstiltak mellom sikkerhetspolitikk og kriminalkontroll.

Tilgangen på digital informasjon gjør at forskjellige former for overvåking integreres stadig mer. For eksempel brukes systemer som er beregnet for kriminalitetskontroll og situasjonsbetinget forebygging også til å takle internasjonale sikkerhetsproblemer som terrorisme. Et klassisk eksempel er overvåkingskameraer. Disse ble opprinnelig konstruert for å forebygge kriminalitet, men er senere tilpasset andre formål - alt fra trafikkontroll til terrorbekjempelse (Barkun 2011: 
45). Fiberoptiske kabler har økt rekkevidden for overvåkingskameraene og dataene de deler, og ansiktsgjenkjenning og biometrisk ID blir i økende grad integrert i politidatabaser som igjen er koblet til overvåkingskameraer (ibid.). Den siste utviklingen er at stordataanalyse tas i bruk for å identifisere og predikere mistenkelig oppførsel - enten man mistenker vanlige forbrytelser eller terrorisme. Aradau og Blanke beskriver for eksempel hvordan stordata blir et sentralt verktøy for forebygging av mange slag, enten det skjer gjennom å samle trådene fra ulike data eller 'å finne nålen i høystakken’ med tanke på terrorbekjempelse (2016). Et annet eksempel er regjeringens forslag om å gi politiet bedre tilgang til forskjellige overvåkingsmetoder (Prop. 68 L (20152016)), som blant annet omfatter «avlytting av samtaler på telefoner, PC og nettbrett, dataavlesing, romavlytting, kontroll av e-post og post, samt skjult kameraovervåking på offentlig og privat sted» (Byhring og Foss 2016). Denne datainnsamlingen er ment å avdekke alt fra «narkotikaovertredelse» til sikkerhetsproblemer av internasjonale dimensjoner, som «oppfordring, rekruttering og opplæring til terrorhandlinger» (Byhring og Foss 2016; Prop. 68 L (2015-2016)).

Disse eksemplene viser at bruk av stordata er muliggjort av ulike ting og teknologier, noe som skaper nye praksiser som kan ha en lokal, nasjonal og internasjonal dimensjon og som bidrar i politiets arbeid med alt fra sykkeltyverier til terrorisme.

\section{Ulike perspektiver for å forstå et sikkerhetsfelt i endring}

Den tendensen Garland beskrev i 1996 til at kriminalitetskontroll gradvis ble flettet sammen med «sikkerhetstankegang», har i de senere årene blitt enda tydeligere. Vi ser denne utviklingen på alle områdene som er drøftet i denne artikkelen, for eksempel i beredskapsspråket, i praktiske sikkerhetstiltak mot terrorisme, og i bruken av stordata i politiarbeid. Samtidig har vi sett at diskurser, praksiser og ting også er relevante utgangspunkt for ulike perspektiver som kan bidra til å belyse denne overlappingen mellom sikkerhetspolitikk og kriminalitetskontroll.

Det narrative perspektivet viser at måten sikkerhet og kriminalitet omtales på ikke bare gjenspeiler, men også påvirker hvordan fenomenene forstås. Helt siden terrorisme ble definert som et fenomen myndighetene ikke kan forutse, har forestillingen om «beredskap» vært definerende i sikkerhetsfeltet. Myndighetenes løfte om å beskytte borgeren er nå blandet med ideen om å gjøre borgeren til en aktiv, forberedt deltaker i sikkerhetspolitikken. 
Overlappingen mellom sikkerhetspolitikk og kriminalitetskontroll blir også tydelig i studier av praksis, beslutninger og administrative rutiner knyttet til terrorbekjempelse. Oppgaver som tidligere var en jobb for eksterne sikkerhetstjenester som PST, er i økende grad også del av interne politioppgaver under POD: den kriminelle er blitt fienden, og krigen mot terror dukker også opp i praksiser som opprettholder offentlig ro og orden. Antiradikalisering er for eksempel en praksis som involverer både PST og POD.

Endelig kan vi også forstå hvordan feltene kriminalitetsbekjempelse og sikkerhetspolitikk føres sammen ved hjelp av spesifikke redskaper. Når mennesker og ting handler med og gjennom hverandre, vil de også forandre hverandre. Og når vi studerer dem, analyserer vi alltid tingen og relasjonen til den.

Kritiske sikkerhetsstudier tilbyr dermed et spesifikt sett med perspektiver som kan bidra til et mer differensiert bilde av fenomener som fortjener vår kritiske oppmerksomhet, som for eksempel sammensmeltingen av kriminalitetskontroll og sikkerhetspolitikk.

\section{Referanser}

Aradau, C. (2010). «Security that matters: Critical infrastructure and objects of protection». Security Dialogue 41 (5), s. 491-514. DOI: https://dx.doi.org/10.1177/0967010610382687.

Aradau, C. og R. van Munster (2011). Politics of Catastrophe. Genealogies of the Unknown. Oxon, NY: Routledge.

Aradau, C. og T. Blanke (2016). «Politics of prediction. Security and the time/space of governmentality in the age of big data». European Journal of Social Theory 20 (3), s. 373-391. DOI: https://dx.doi.org/10.1177/1368431016667623

Balzacq, T., T. Basaran, D. Bigo, E.P. Guittet og C. Olsson (2010, 15. februar). «Security Practices». International Studies Encyclopedia Online. http://www.open.ac.uk/researchprojects/iccm/files/iccm/olsson-christian-publication7.pdf. [Sist lastet ned 19.08.16].

Barad, K. (2007). Meeting the Universe Halfway: Quantum Physics and the Entanglement of Matter and Meaning. Durham, NC: Duke University Press.

Barkun, M. (2011). Chasing Phantoms. Reality, Imagination and Homeland Security Since 9/11. Chapel Hill, NC: University of North Carolina Press.

Bellanova, R. og G.-G. Fuster (2013). «Politics of disappearance: Scanners and (unobserved) bodies as mediators of security practices». International Political Sociology 7 (2), s. 188-209. DOI: https://dx.doi.org/10.1111/ips.12017. 
Bigo, D. (2002). «Security and immigration. Toward a critique of the governmentality of unease». Alternatives 27 (1), s. 63-92. DOI: https://dx.doi.org/10.1177/03043754020270s105.

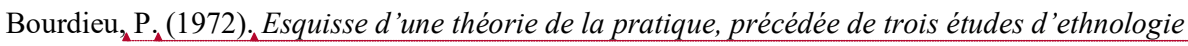
kabyle. Geneve: Droz.

Bueger, C. (2017). «Security as practice». I T. Balzacq og M.D. Cavelty (red.), Routledge Handbook of Security Studies, 2. utgave, s. 126-135.

Burgess, P. (2010). The Routledge Handbook of New Security Studies. Oxon, New York: Routledge.

Bush, G.W. (2002, 29. januar). «State of the Union». Tale. https://georgewbushwhitehouse.archives.gov/news/releases/2002/01/20020129-11.html. [Sist lastet ned 20.12.16].

Byhring, P. og A.B. Foss (2016, 23. februar). «Slik blir politiets nye overvåkingshverdag». Aftenposten. [Sist lastet ned 29.09.16].

Côté-Boucher, K., F. Infantino og M. Salter (2014). «Border security as practice: An agenda for research». Security Dialogue 45 (3), s. 195-208. DOI:

https://dx.doi.org/10.1177/0967010614533243.

Foucault, M. (1972). The Archaeology of Knowledge. Overs. A.S. Smith. New York: Pantheon Books.

Garland, D. (1996). «The limits of the sovereign state. Strategies of crime control in contemporary society». British Journal of Criminology 36 (4), s. 445-471. DOI: https://dx.doi.org/10.1093/oxfordjournals.bjc.a014105.

Hall, S. (1997). «The work of representation». I Hall (red.), Representation: Cultural Representations and Signifying Practices. London: Sage, s. 1-74.

Kaufmann, M. (2017). Resilience, Emergencies and the Internet: Security In-Formation. London, New York: Routledge.

Kaufmann, M. og J. Jeandesboz (2016). «Politics and 'the digital': From singularity to specificity». European Journal of Social Theory 20 (3), s. 309-328. DOI: https://dx.doi.org/10.1177/1368431016677976.

Latour, B. (2005). Reassembling the Social: An Introduction to Actor-Network-Theory. Oxford: Oxford University Press.

Prop. 68 L (2015-2016). «Endringer i straffeprosessloven mv. (skjulte tvangsmidler)». https://www.regjeringen.no/no/dokumenter/prop.-68-1-20152016/id2479232/sec1. [Sist lastet ned 29.09.16]. 
Reckwitz. A. (2002). «Toward a theory of social practices: A development in culturalist theorizing». European Journal of Social Theory 5 (2), s. 243-63. DOI: https://dx.doi.org/10.1177/13684310222225432.

Regjeringen (2015a). «Justis- og beredskapsdepartementet». https://www.regjeringen.no/no/dep/jd/id463/. [Sist lastet ned 11.12.17].

Regjeringen (2015b). «Politiavdelingen».

https://www.regjeringen.no/no/dep/jd/org/avdelinger/pia/id1469/. [Sist lastet ned 22.08.16].

Regjeringen (2016). «Politiets sikkerhetstjeneste (PST) og radikalisering».

https://www.regjeringen.no/no/sub/radikalisering/veileder/bekymret/pst/id2401813/. [Sist lastet ned 22.08.16].

Rumsfeld, D. (2002, 12. februar). «DoD News Briefing - Secretary Rumsfeld and Gen. Myers. Presenter: Secretary of Defense Donald H. Rumsfeld».

http://archive.defense.gov/Transcripts/Transcript.aspx?TranscriptID=2636. [Sist lastet ned 01.08.16].

Salter, M. og C.E. Mutlu (2013). Research Methods in Critical Security Studies. An Introduction. London, New York: Routledge.

Trædal, T.J. (2016, 12. februar). «Smedsrud blir ny beredskapsdirektør». Politiforum.

Waltz, K. (1959). Man, the State, and War. New York: Columbia University Press.

Wæver, O. (1995). «Securitization and desecuritization». I R.D. Lipschutz (red.), On Security. New York: Columbia University Press, s. 46-86. 